\title{
Variation of selected genotoxic and epigenetic markers due to therapeutic exposure to PAHs and ultraviolet radiation
}

\author{
Borsky $\mathrm{P}^{1,2}$, Chmelarova $\mathrm{M}^{3}$, Fiala $\mathrm{Z}^{1}$, Palicka $\mathrm{V}^{3}$, Beranek $\mathrm{M}^{3,4}$, Kremlacek $\mathrm{J}^{2}$, Andrys $\mathrm{C}^{5}$, \\ Hamakova $\mathrm{K}^{6}$, Malkova $\mathrm{A}^{1}$, Borska $\mathrm{L}^{2}$ \\ Institute of Hygiene and Preventive Medicine, Charles University in Prague, Faculty of Medicine in Hradec Kralove, \\ Hradec Kralove, Czech Republic. borskyp@Ifhk.cuni.cz
}

\begin{abstract}
BACKGROUND: Goeckerman therapy (GT) of psoriasis involves dermal application of crude coal tar containing polycyclic aromatic hydrocarbons (PAHs) and exposure to ultraviolet radiation (UVR). Little is known about GT influence on DNA epigenetics.

OBJECTIVE: The study aim was to discover epigenetic mechanisms altered by the exposure related to the GT of psoriasis.

METHODS: Observed group of patients with plaque psoriasis $(n=23)$ was treated by GT with $3 \%$ CCT.

Before and after GT, we analyzed the levels of benzo[a]pyrene-7,8-diol-9,10-epoxide-DNA adducts (BPDE-

DNA), p53 protein in serum, 5-methylcytosine (5-mC, global DNA methylation), and methylation in selected CpG sites of p53 gene.

RESULTS: We found a significant increase in the levels of BPDE-DNA $(p<0.01)$ and serum levels of p53 protein $(p<0.01)$ after GT, and an insignificant decrease in the percentage of 5 -mC in peripheral blood DNA. Methylation of p53 CpG sites was affected neither by psoriasis nor by GT. The study confirmed good effectiveness of GT (significantly reduced psoriasis area and severity index; $p<0.001$ ).

CONCLUSION: Our findings indicate that there is a significantly increased genotoxic hazard related to the exposure of PAHs and UV radiation after GT of psoriasis. However, global DNA methylation and p53 gene methylation evade the effect of GT, as they remained unchanged (Tab. 4, Fig. 3, Ref. 50). Text in PDF www.elis.sk KEY WORDS: psoriasis, Goeckerman therapy, methylation, polycyclic aromatic hydrocarbons, UV radiation.
\end{abstract}

\section{Psoriasis}

Psoriasis is a multifactorial relapsing and remitting inflammatory skin disease. The prevalence of psoriasis ranged from $1.4 \%$ to $3.3 \%$ in Europe and North America (1-3). The disease (most often referred to as plaque psoriasis) represents about $4 \%$ of all dermatoses which manifest at 16 years of age or younger $(4,5)$.

${ }^{1}$ Institute of Hygiene and Preventive Medicine, Charles University in Prague, Faculty of Medicine in Hradec Kralove, Hradec Kralove, Czech Republic, ${ }^{2}$ Institute of Pathological Physiology, Charles University in Prague, Faculty of Medicine in Hradec Kralove, Hradec Kralove, Czech Republic, ${ }^{3}$ Institute of Clinical Biochemistry and Diagnostics, Charles University Hospital and Faculty of Medicine in Hradec Kralove, Hradec Kralove, Czech Republic, ${ }^{4}$ Department of Biochemical Sciences, Charles University in Prague, Faculty of Pharmacy in Hradec Kralove, Hradec Kralove, Czech Republic, ${ }^{5}$ Institute of Clinical Immunology and Allergology, Charles University in Prague, Faculty of Medicine in Hradec Kralove, Hradec Kralove, Czech Republic, and ${ }^{6} \mathrm{Clinic}$ of Dermal and Venereal Diseases, Charles University Hospital Hradec Kralove, Hradec Kralove, Czech Republic

Address for correspondence: Pavel Borsky, MD, Institute of Hygiene and Preventive Medicine, Charles University, Faculty of Medicine in Hradec Kralove, Šimkova 870, CZ-500 38 Hradec Králové, Czech Republic.

Acknowledgement: This study was supported by Charles University in Prague, Faculty of Medicine in Hradec Kralove, Czech Republic, Projects PROGRES Q40/09, PROGRES Q40/10, PROGRES Q40/11 and project SVV-260543/2020 and by Ministry of Health, Czech Republic - conceptual development of research organization MH CZ - DRO (FNHK) 00179906.
Goeckerman therapy

Goeckerman Therapy (GT) represents an effective treatment of moderate to severe plaque psoriasis using a combination of pharmaceutical grade crude coal tar (CCT) and artificial ultraviolet radiation (UVR) (6). It was first formulated in 1925 by dermatologist William H. Goeckerman. The therapy continues to be used due to its efficacy and low cost (7). However, the use of GT has recently decreased for several reasons, including suspected mutagenicity/ carcinogenicity of CCT and UVR (8-10).

\section{CCT/PAHs/DNA-BPDE}

The mutagenic/carcinogenic effect of CCT is primarily attributed to polycyclic aromatic hydrocarbons (PAHs). Some of them were recognized as potent environmental mutagens and carcinogens (11). During biotransformation, they are subject to bioactivation, resulting in expression of reactive metabolites which are capable of binding to DNA and proteins (formation of adducts). A typical representative of mutagenic/carcinogenic PAHs, benzo[a]pyrene $(\mathrm{BaP})$, is bioactivated into a highly reactive metabolite benzo[a] pyrene-7,8-diol-9,10-epoxide (BPDE) which is capable of covalent binding to DNA and formation of DNA-BPDE adducts $(9,12)$.

UVR

Ultraviolet radiation $\mathrm{B}$ (UVB) is well known as radiation that can cause severe damage to DNA. However, the results of recent 
studies showed that also ultraviolet radiation A (UVA) can be a potent inductor of DNA damage that may be associated with genotoxicity and skin cancer (13). The combination of UVA and UVB was officially classified as carcinogenic to humans (14). Moreover, it was shown that UVA in combination with other common environmental pollutants (including PAHs) can significantly increase the risk of carcinogenesis (15). It therefore seems likely that DNA damage induced by UVA and UVB during GT can be further increased by co-exposure to PAHs (16).

\section{Protein $p 53$}

The $\mathrm{p} 53$ protein is a $53-\mathrm{kD}$ nuclear phosphoprotein (393 amino acids). It is a product of a $20-\mathrm{Kb}$ gene that is localized on the short arm of human chromosome 17, at position 17pl3.1 (17) and comprises 11 exons. The $\mathrm{p} 53$ promoter region has been sequenced, and basal promoter activity localized to the 85 bp region (nucleotide 760-844) which is indispensable for full promoter activity (18). It has putative binding sites for transcriptional factors. This protein is the principal mediator of cell-cycle arrest (G1/S arrest), gene transcription, genomic stability and apoptosis in response to a broad array of stressors, including but not limited to DNA damage (induced by UVR, infrared radiation, or chemical agents such as PAHs), oxidative stress, osmotic shock and deregulated oncogene expression (19-21). In human cancers, the $\mathrm{p} 53$ protein mutations are the most frequent genetic defects. Mutations in the $\mathrm{p} 53$ protein often result in a prolonged half-time of the protein compared with the wild-type p53 leading to its accumulation in cell nuclei (22).

\section{Epigenetics - methylation}

The role of epigenetics in gene regulation is undisputed. Epigenetics can be described as a stable alteration in gene expression potential that takes place during development and cell proliferation without any changes in the gene sequence. Epigenetic mechanisms such as DNA methylation, histone modification, nucleosome positioning and non-coding RNAs are proven to have a strong association with carcinogenesis $(23,24)$. The DNA methylation is one of the most common epigenetic events taking place in the mammalian genome (as repressor of gene expression). The methylation is based on covalent chemical modification mediated by DNA cytosine methyltransferases, resulting in addition of a methyl group at the carbon 5 position of the cytosine ring. Most of the cytosine methylation occurs in the sequence context 5'CG3' (25). Generally, it can be said that the cancer phenotype is usually characterized by global DNA hypomethylation and gene-specific hypermethylation $(26,27)$.

\section{Methylation and pollutants}

The DNA methylation patterns are known to be affected by environmental chemicals, lifestyle factors and demographic factors $(28,29)$. Among others, PAHs and UVR have been reported to induce epigenetic alterations that may contribute to the development of mutagenesis and carcinogenesis $(27,29,30)$.

\section{Aim of the study}

Based on the above, it can be assumed that both, genotoxic and epigenetic mechanisms of carcinogenesis could participate in exposure/metabolic scenarios (repeated combined therapeutic exposure to PAHs and UVR). Verification of this assumption presents the main target of the presented study. For this purpose, we studied a group of patients with psoriasis treated with GT. Based on our previous experience $(9,31)$, two indicators of genotoxic mechanisms and two indicators of epigenetic mechanisms of carcinogenesis were selected.

To prove the presence of genotoxic mechanisms, we used the changes in blood level of DNA-BPDE adducts and serum level of the p53 protein. For the evidence of epigenetic mechanisms, we selected the changes in the levels of global DNA methylation (the level of 5-methylcytosine in blood cells) and gene-specific methylation on the p53 gene in blood cells.

\section{Material and methods}

\section{Study group}

Experimental data were collected over the period of two years. The examined group consisted of 23 adult patients ( 12 women and 11 men, average age of 40 years, age variance of $18-75$ years, 11 moderate smokers and 12 nonsmokers) with chronic stable plague psoriasis treated with GT (Clinic of Dermal and Venereal Diseases, University Hospital Hradec Kralove, Czech Republic). Using a questionnaire, we checked the patients as to the presence of excessive exposure to PAHs and/or artificial UVR prior to the therapy. The patients who had prior excessive exposure to PAHs and/or artificial UVR had to be excluded from the study group. The study was approved by the Ethics Committee of the University Hospital in Hradec Kralove, Czech Republic. Informed written consent was obtained from each patient.

\section{Collection of biological samples}

The samples of whole peripheral blood and EDTA-treated whole peripheral blood were collected a day before the first treatment and immediately after the last procedure of GT. The sample processing is described in the methods of determining the individual indicators.

\section{Goeckerman therapy}

Dermatological tar ointment containing 3\% of CCT was applied daily overnight to psoriatic lesions (10-75\% of total body surface in monitored group). The content of $\mathrm{BaP}$ in the mixed sample of CCT was $0.008 \mathrm{mg} / \mathrm{g} \mathrm{CCT}$. In the morning, the residue of ointment was removed from the body (using oil bath) and the patients were whole-body irradiated by UVR. The irradiation was dosed individually according to the severity of the disease and reaction of skin to the therapy (range 1-15 min of irradiation). The density of used radiation was $248.17 \mu \mathrm{W} / \mathrm{cm}^{2}$ for UVB and $132.1 \mu \mathrm{W} / \mathrm{cm}^{2}$ for UVA (controlled by Sola-Scope 2000 spectrometer; Solatell, UK) The duration of therapy was modified according to the extent and severity of the disease and effectiveness of the therapy (average duration of 13 days; range of 10-22 days). The effectiveness of the therapy was evaluated according to the level of erythema, desquamation, and skin infiltration (psoriasis area severity index; PASI score) (32). Gene- 
rally, the treatment was terminated when PASI score reached a decrease by $50 \%$.

\section{Serum level of protein $p 53$}

Samples of whole peripheral blood were allowed to clot and serum was obtained after sample centrifugation at $700 \mathrm{~g}$. Serum samples were stored frozen at $-70{ }^{\circ} \mathrm{C}$. Serum levels of $\mathrm{p} 53$ protein were measured using commercial ELISA kit (p53 TiterZyme EIA; Assay Designs, Ann Arbor, MI, USA) according to manufacturer's instructions. Monoclonal antibody to p53 immobilized on a microtiter plate binds p53 in the standards (purified p53) or sample. Subsequently a polyclonal antibody to p53 labeled with the enzyme horseradish peroxidase was added. After incubation and washing, the enzyme substrate is added and the developed color (measured at $450 \mathrm{~nm}$ ) is directly proportional to the concentration of $\mathrm{p} 53$ in $\mathrm{pg} / \mathrm{ml}$.

Benzo[a]pyrene-7,8-diol-9,10-epoxide-DNA adducts (DNABPDE adducts)

EDTA-treated whole peripheral blood specimens were collected immediately after GT. Genomic DNA was extracted from $200 \mathrm{ml}$ of blood with a QIAamp DNA Blood Mini Kit (Qiagen, Germany). The extracts were subsequently diluted to a concentration of $2 \mathrm{mg}$ of DNA in $1 \mathrm{ml}$. The level of BPDE-DNA adducts was determined using the standard method of OxiSelect BPDE-DNAAdduct ELISA Kit (Cell Biolabs, USA) according to manufacturer's instructions. This sandwich-based immunoassay was previously characterized by a high level of consistency and between-day precision ( $\mathrm{Su}$ et al, 2014). Colorimetric measurements of BPDE-DNA were made at $450 \mathrm{~nm}$ using a Multiskan RC microplate reader (Labsystems Diagnostics, Finland). To minimize background signals from unadducted DNA non-specific binding, the reduced DNA standard (Cell Biolabs, USA) was used as an absorbance blank. For quantification, an eight-point BPDE-DNA standard curve (measuring range of $0-100 \mathrm{ng} / \mathrm{mL}$ ) was included in each run. The results were expressed as nanograms of BPDEDNA adducts per microgram of DNA. All samples were assayed in duplicate.

\section{Global DNA methylation (the level of 5-methylcytosine)}

DNA samples, isolated from the samples of whole peripheral blood (100 ng), were used for the analysis of global DNA methylation. The level of 5-mC (5-methylcytosine) was determined using the 5-mC DNA ELISA Kit (Zymo Research Corporation, USA) according to manufacturer's instructions. Denatured, single-stranded DNA samples are coated on well surfaces of the microtiter plate. The anti-5-methylcytosine monoclonal antibody and HRP-conjugated secondary antibody are added to the wells. Photometric detection of 5-mC occurs after the addition of HRP developer. The percentage of 5-mC in a DNA sample was accurately quantified from a standard curve generated with specially designed controls included with the kit.

Methylation of promoter region of the p53 gene (methylation-specific PCR)

DNA methylation patterns in $\mathrm{CpG}$ islands of the promoter region of the $\mathrm{p} 53$ gene were determined by methylation-specific
PCR (MSP) (33). Sodium bisulfite modification was performed using the EZ DNA Methylation-Gold ${ }^{\mathrm{TM}}$ Kit (Zymo Research Corporation, USA) according to the manufacturer's protocol with minor modifications. DNA was resuspended in elution buffer and stored at $-80^{\circ} \mathrm{C}$.

Primer sequences have been reported previously (34), namely 5'-TTGGTAGGTGGATTATTTGTTT-3' (sense) and 5' -CCAATCCAAAAAAACATATCAC-3' (antisense) for unmethylated reaction (PCR product $247 \mathrm{bp}$ ), and 5'-TTCGGTAGGCGGATTATTTG-3' (sense) and 5'-AAATATCCCCGAAACCCAAC-3' (antisense) for methylated reaction (PCR product $193 \mathrm{bp}$ ). PCR was carried out in a $25-\mu 1$ mixture, containing 10x Takara buffer $(2.5 \mu \mathrm{l})$, dNTPs $2.5 \mathrm{mM}$ solution Takara $(2.0 \mu \mathrm{l})$, primers $(1 \mu \mathrm{l}$ each $10 \mathrm{pmol} / \mu \mathrm{l}$ solution), polymerase Taq HS Takara $5 \mathrm{U} / \mu \mathrm{l}(0.3 \mu \mathrm{l})$ (Takara Bio Europe S.A.S, France), water and $2 \mu$ of bisulfitemodified DNA in a Veriti Thermocycler (Applied Biosystems, CA). The cycling condition consisted of an initial denaturation at $95{ }^{\circ} \mathrm{C}$ for $7 \mathrm{~min}, 40$ cycles of denaturing at $95^{\circ} \mathrm{C}$ for $45 \mathrm{~s}$, annealing at $59{ }^{\circ} \mathrm{C}$ for $45 \mathrm{~s}$, and extension at $72{ }^{\circ} \mathrm{C}$ for $60 \mathrm{~s}$, followed by final extension for $5 \mathrm{~min}$ at $72{ }^{\circ} \mathrm{C}$. CpG universal methylated and unmethylated DNA (Zymo Research Corporation, USA) were also treated with bisulfite and used as controls. Amplified products were electrophoresed on $2 \%$ agarose gels and visualized under ultraviolet light after staining with ethidium bromide.

\section{Statistical analysis}

Obtained data were analyzed by using MATLAB rel. 2014a software (Mathworks, Inc., Massachusetts, USA). Because the Lilliefors test of normality had rejected the hypothesis of normal distribution, the data were analyzed by the Wilcoxon signed-rank one-tailed test. The possible associations between monitored biomarkers and important factors of exposure were evaluated by using the Spearman rank-order test. The findings were considered significant when the probability level (p) was below 0.05 .

\section{Results}

Based on the significant decrease in the value of PASI score $(\mathrm{p}<0.001)$, we can state that the efficacy of the therapy was sufficiently high (Tab. 1). The effect of smoking on the disease status

Tab. 1. The influence of GT and smoking on the level of PASI score ${ }^{a}$.

\begin{tabular}{|c|c|c|}
\hline \multicolumn{2}{|c|}{ Whole group (smokers and nonsmokers) } & \multirow{2}{*}{$\begin{array}{l}\text { Significance } \\
\text { of difference }\end{array}$} \\
\hline Before GT $(n=23)$ & After GT $(n=23)$ & \\
\hline $\begin{array}{c}16.20 \\
(12.70-20.85)\end{array}$ & $\begin{array}{c}7.80 \\
(6.60-10.75) \\
\end{array}$ & $\mathrm{p}<0.001(0.0000)$ \\
\hline \multicolumn{2}{|c|}{ Nonsmokers } & \multirow{2}{*}{$\begin{array}{l}\text { Significance } \\
\text { of difference }\end{array}$} \\
\hline Before GT $(\mathrm{n}=12)$ & After GT $(n=12)$ & \\
\hline $\begin{array}{c}15.00 \\
(12.55-20.10) \\
\end{array}$ & $\begin{array}{c}8.00 \\
(6.65-9.20) \\
\end{array}$ & $\mathrm{p}<0.001(0.0002)$ \\
\hline \multicolumn{2}{|c|}{ Smokers } & Significance \\
\hline Before GT $(n=11)$ & After GT(n=11) & of difference \\
\hline $\begin{array}{c}19.20 \\
(14.85-20.85) \\
\end{array}$ & $\begin{array}{c}7.60 \\
(6.38-12.45) \\
\end{array}$ & $\mathrm{p}<0.001(0.0005)$ \\
\hline
\end{tabular}

${ }^{a}$ The values of PASI score are presented as median and lower - upper quartile because of non-normal data distribution; $\mathrm{p}=$ Wilcoxon matched-pairs test 
Tab. 2. The influence of GT and smoking on level of the p53 proteina.

\begin{tabular}{|c|c|c|}
\hline \multicolumn{2}{|c|}{ Whole group (smokers and nonsmokers) } & \multirow{2}{*}{$\begin{array}{l}\text { Significance } \\
\text { of differences }\end{array}$} \\
\hline Before GT $(n=23)$ & After GT $(n=23)$ & \\
\hline $\begin{array}{c}6.10 \\
(4.50-9.40)\end{array}$ & $\begin{array}{c}9.20 \\
(6.20-13.00) \\
\end{array}$ & $\mathrm{p}<0.01(0.0022)$ \\
\hline \multicolumn{2}{|c|}{ Non-smokers } & Significance \\
\hline Before GT $(n=12)$ & After GT $(n=12)$ & of differences \\
\hline $\begin{array}{c}5.45 \\
(4.20-9.00) \\
\end{array}$ & $\begin{array}{c}9.05 \\
(6.65-11.20) \\
\end{array}$ & $\mathrm{p}<0.01(0.0012)$ \\
\hline \multicolumn{2}{|c|}{ Smokers } & Significance \\
\hline Before GT $(\mathrm{n}=11)$ & After GT $(n=11)$ & of differences \\
\hline $\begin{array}{c}8.50 \\
(4.68-13.75) \\
\end{array}$ & $\begin{array}{c}9.0 \\
(5.43-16.70) \\
\end{array}$ & NS $(0.1392)$ \\
\hline
\end{tabular}

${ }^{a}$ The values of the $\mathrm{p} 53$ protein (picograms of $\mathrm{p} 53$ per milliliter of serum) are presented as median and lower - upper quartile because of non-normal data distribution; $p=$ Wilcoxon matched-pairs test
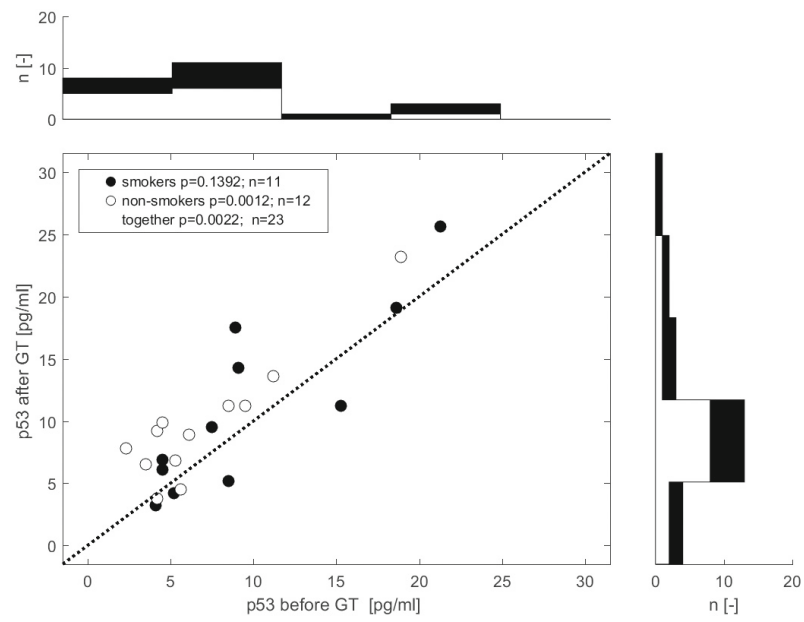

Fig. 1. Distribution of serum levels of the p53 protein. The levels are expressed as picograms of the $\mathbf{p 5 3}$ protein per $\mathrm{ml}$ of serum. The scatter plot depicts the $\mathbf{p 3}$ protein values before and after GT. Each dot belongs to one patient. The top histogram shows data distribution before treatment; the right-side histogram corresponds to the posttreatment values distribution. The white and black zones represent data on nonsmokers and smokers, respectively.

(PASI score) was not significant in our study group. The differences in the level of PASI scores between smokers and non-smokers were as follows: $\mathrm{p}=0.4055$ before GT and $\mathrm{p}=0.8055$ after GT.

The therapy significantly increased serum level of the p53 protein in the whole group of patients $(\mathrm{p}<0.01)$, however there were some differences in the biological answer when the group was divided into smokers and non-smokers (NS for smokers and $\mathrm{p}<0.01$ for non-smokers). The scatter plot shown below depicts the distribution of serum levels of the p 53 protein before and after GT while considering the smoking status of patients (Tab. 2, Fig. 1). The effect of smoking on the serum level of the $\mathrm{p} 53$ protein was not significant in our study group. The differences in the p53 protein levels between smokers and nonsmokers were as follows: $\mathrm{p}=0.2672$ before GT and $\mathrm{p}=0.8293$ after GT.

In the present study we used MSP for analysis of methylation in 553 gene to analyze samples from 22 patients with chronic
Tab. 3. The level of BPDE-DNA adducts before and after the therapy.

\begin{tabular}{|c|c|c|}
\hline \multicolumn{2}{|c|}{ BPDE-DNA adducts (smokers and nonsmokers) } & \multirow{2}{*}{$\begin{array}{l}\text { Significance } \\
\text { of differences }\end{array}$} \\
\hline Before GT $(n=21)$ & After GT $(n=21)$ & \\
\hline $\begin{array}{c}9.50 \\
(8.45-11.50)\end{array}$ & $\begin{array}{c}11.80 \\
(9.80-15.00)\end{array}$ & $\mathrm{p}<0.01(0.0075)$ \\
\hline \multicolumn{2}{|c|}{ BPDE-DNA adductsc (nonsmokers) } & \multirow{2}{*}{$\begin{array}{l}\text { Significance } \\
\text { of differences }\end{array}$} \\
\hline Before GT $(n=10)$ & After GT $(n=10)$ & \\
\hline $\begin{array}{c}9.35 \\
(8.00-11.50) \\
\end{array}$ & $\begin{array}{c}10.65 \\
(8.60-13.20) \\
\end{array}$ & NS (0.0654) \\
\hline \multicolumn{2}{|c|}{ BPDE-DNA adductsc (smokers) } & \multirow{2}{*}{$\begin{array}{c}\text { Significance } \\
\text { of differences }\end{array}$} \\
\hline Before GT $(\mathrm{n}=11)$ & After GT $(\mathrm{n}=11)$ & \\
\hline $\begin{array}{c}9.90 \\
(8.68-11.33)\end{array}$ & $\begin{array}{c}12.30 \\
(11.03-21.08) \\
\end{array}$ & $\mathrm{p}<0.05(0.0269)$ \\
\hline
\end{tabular}

The levels are expressed as ng of BPDE-DNA adducts per $\mu \mathrm{g}$ of DNA and the average concentration is presented as median and lower-upper quartile because of non-normal data distribution; $\mathrm{p}=$ Wilcoxon matched-pairs test; $\mathrm{NS}=$ non-significant difference

Tab. 4. Percent of 5-mC before and after the therapy.

\begin{tabular}{|c|c|c|}
\hline \multicolumn{2}{|c|}{ Methylation (smokers and nonsmokers) } & \multirow{2}{*}{$\begin{array}{l}\text { Significance } \\
\text { of differences }\end{array}$} \\
\hline Before GT $(n=22)$ & After GT $(n=22)$ & \\
\hline $\begin{array}{c}3.55 \\
(2.10-8.50)\end{array}$ & $\begin{array}{c}3.35 \\
(2.50-7.50)\end{array}$ & NS (0.7189) \\
\hline \multicolumn{2}{|c|}{ Methylationa (nonsmokers) } & \multirow{2}{*}{$\begin{array}{c}\text { Significance } \\
\text { of differences }\end{array}$} \\
\hline Before GT $(\mathrm{n}=11)$ & After GT $(n=11)$ & \\
\hline $\begin{array}{c}5.50 \\
(2.50-9.65) \\
\end{array}$ & $\begin{array}{c}7.50 \\
(3.00-10.05)\end{array}$ & NS (0.9004) \\
\hline \multicolumn{2}{|c|}{ Methylationa (smokers) } & Significance \\
\hline Before GT $(n=11)$ & After GT $(n=11)$ & of differences \\
\hline $\begin{array}{c}3.20 \\
(2.10-4.13)\end{array}$ & $\begin{array}{c}2.80 \\
(1.95-3.43)\end{array}$ & NS $(0.3120)$ \\
\hline
\end{tabular}

Percent of 5-mC in a DNA sample is presented as median and lower-upper quartile because of non-normal data distribution; $\mathrm{p}=$ Wilcoxon matched-pairs test; NS = non-significant difference
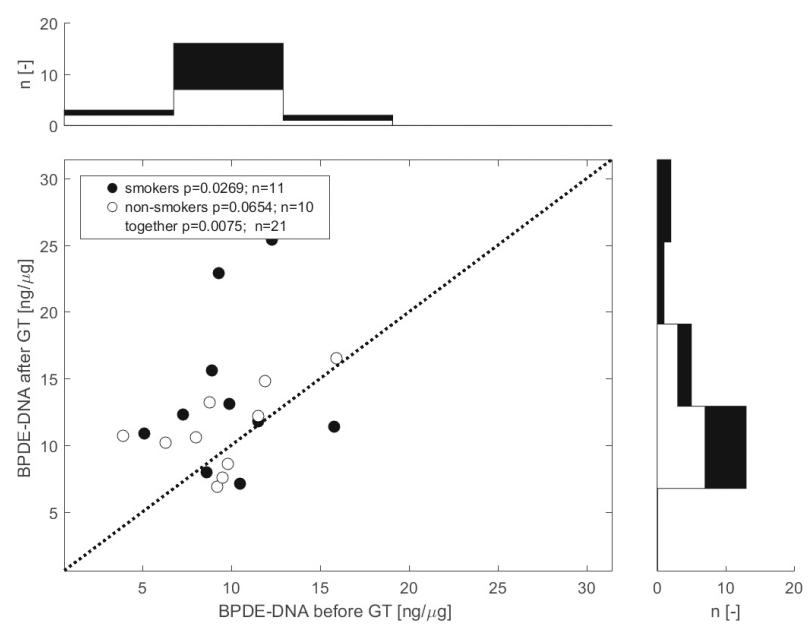

Fig. 2. Distribution of values of BPDE-DNA adducts. The levels are expressed as ng of BPDE-DNA adduct per $\mu \mathrm{g}$ of DNA. The scatter plot depicts BPDE-DNA values before and after GT. Each dot belongs to one patient. The top histogram shows data distribution before treatment; the right-side histogram corresponds to the posttreatment values distribution. The white and black zones represent data on nonsmokers and smokers, respectively. 
558-564
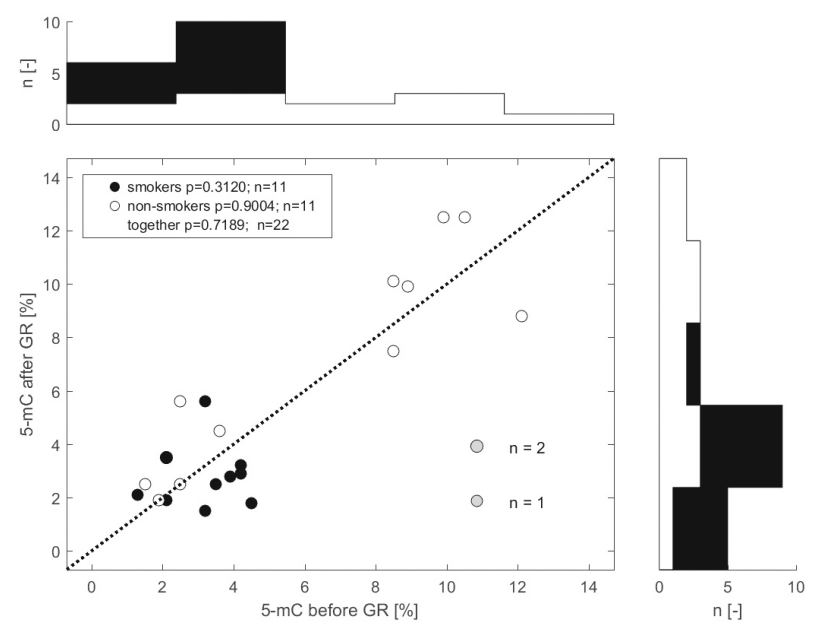

Fig. 3. Distribution of values of 5-mC. The levels are expressed as percent of 5-mC in DNA. The scatter plot depicts 5-mC values before and after GT. Each dot belongs to one patient. The top histogram shows data distribution before treatment; the right-side histogram corresponds to the posttreatment values distribution. The white and black zones represent data on nonsmokers and smokers, respectively.

stable plague psoriasis treated with GT. Using MSP for p53, methylation was observed in patients neither before nor after the treatment. Tables 3 and 4 summarize the results of biomonitoring of the genotoxic effect associated with the application of GT in the observed group. After GT, we found a significantly increased level of BPDE-DNA adducts $(\mathrm{p}<0.01)$. No significant changes were found in the percentage of 5-mC before or after GT. Scatter plots (Figs 2 and 3) depict the distribution of values of 5-mC and BPDE-DNA before and after GT. Each dot belongs to one patient.

\section{Discussion}

We found a significant decrease in the PASI score after GT. The decrease was recorded in the subgroups of smokers $(p=0.0005)$ and nonsmokers $(p=0002)$, as well as in the sub-group involving both smokers and nonsmokers $(\mathrm{p}=0.0000)$. Table 1 shows an appreciable but statistically nonsignificant difference $(p=0.4055)$ between the average values in the PASI score (before the therapy) in smokers (19.20) and nonsmokers (15.00). However, after the therapy the corresponding average values of the PASI score in both subgroups were decreased at an almost same level; 7.60 in smokers and 8.00 in non-smokers. This effect may be related to the smoking habit of patients before hospitalization and to the strong influence of the therapy. It should be noted that according to questionnaire responses, the patients were moderate, irregular smokers (up to 10 cigarettes per day before hospitalization) and their smoking was substantially reduced during hospitalization.

Carcinogenicity of PAHs and UV radiation (as a part of GT) has been studied in experimental animals and in humans. However, there is still only a limited amount of data on the carcinogenicity of GT. However, it is evident that both components of the therapy (CCT and UVR) present a relatively high carcinogenic potential.
Moreover, in a situation of combined exposure to PAHs and UV radiation, their synergistic effect on generation of ROS (reactive oxygen species), lipid peroxidation, and DNA damage can be expected $(15,35)$. This is important in order to find suitable bioindicators for the genotoxic risk of GT that can destabilize the genetic cellular homeostasis. This would be important mainly for patients at higher risk of cancer, such as those with BRCA1, 2 or p53 germline mutations.

In normal cells, wtp53 appears to be typically present in a latent form of $\mathrm{p} 53$. The steady-state levels of latent $\mathrm{p} 53$ are extremely low owing to a very rapid rate of proteolytic degradation. In normal cells or tumor cells that still retain wtp53 expression, the activation of endogenous wtp53 in response to extracellular or intracellular stimuli results in accumulation of a stabilized, biochemically altered protein $(36,37)$. The increase in wtp53 activity can lead to various cellular outcomes such as cell cycle arrest and induction of apoptosis. It is believed that these dramatic biological effects of activated wtp53 may mediate much of its tumor suppressor function, particularly when they occur in cells which have accumulated defects in their DNA or chromosomes. In such situations, the activation of $\mathrm{p} 53$ would prevent the perpetuation of genomic damage, and ensure that these potentially dangerous cells will not multiply and take over the normal population (38).

The presence of protein p53 in plasma is recognized as an indicator of cell response to DNA damage (39). It has been reported that increased blood serum protein $\mathrm{p} 53$ concentrations have a prognostic value in early diagnosis of lung cancer caused by previous airborne exposure to PAHs (39). In addition, serum levels of p53 in some cases are elevated prior to the time of clinical diagnosis of the disease risk, and thus may be an early biomarker (40). In accordance with this study, we found significantly increased serum levels of $\mathrm{p} 53$ after dermal exposure to PAHs in our patients with psoriasis, namely 6.10/4.50-9.40 pg/mL (median/lower-upper quartile) vs. 9.20/6.20-13.00 pg/ml (median/lower-upper quartile) for $\mathrm{p} 53$ before and after GT, respectively; $\mathrm{p}<0.01$.

PAHs may exert their mutagenic, genotoxic, and carcinogenic properties by two major mechanisms. One pathway includes an induction of oxidative stress; the second one includes a formation of specific PAHs-DNA adducts (41). Benzo(a)pyrene is notable for being the first chemical carcinogen to be discovered. BaP is a five-ring PAH known to be a procarcinogen. Its mechanism of carcinogenesis is dependent on a three-step process of enzymatic metabolism leading to the final mutagen. The steps include a generation of benzo(a)pyrene-7,8-epoxide, benzo(a)pyrene-7,8-diol, and finally benzo(a)pyrene-7,8-diol-9,10-epoxide (BPDE). The very reactive BPDE binds covalently to proteins, lipids, and DNA (guanine residues) to produce BPDE-DNA adducts. If left unrepaired, DNA adducts may lead to permanent mutations resulting in cell transformation and ultimately to tumor development (42). Biological monitoring includes indicators of exposure, biological effect, and susceptibility. The BPDE-DNA adducts can be indicative of both exposure and genotoxic effect of $\mathrm{BaP}$. The level of BPDE-DNA adducts is determined by the character of BaP metabolism (metabolic enzyme activities) and by the degree of reparation mechanisms. In Table 4, it is shown that the level of BPDE- 
DNA adducts was significantly increased after the therapy $(9.5 \mathrm{vs}$ $11,8 \mathrm{ng}$ BPDE-DNA adducts/ $\mu \mathrm{g}$ DNA; $\mathrm{p}<0.01$ ), which indicates an increased hazard of genotoxic effect related to the treatment.

Human tumors undergo a global overall loss of DNA methylation which affects the chromosome stability, but also they acquire hypermethylation at specific promoters $(43,44)$. Increased methylation in the transcribed region has a variable effect on gene expression. Several mechanisms have been proposed to account for transcriptional repression by DNA methylation. The first mechanism involves direct interference with the binding of specific transcription factors to their recognition sites in their respective promoters (45). The second mode of repression involves a direct binding of specific transcription repressors to methylated DNA (46). DNA methylation can also affect histone modification and chromatin structure, which in turn can alter the gene expression (47). Compared to normal cells, the malignant cells show major disruptions of their DNA methylation patterns (25). The underlining mechanisms that cause these changes are unknown, but there is a suggestion that at least a subset of DNA methylation changes occurs early in tumor development and may even initiate carcinogenesis.

Most research has been concerned with local hypermethylation of $\mathrm{CpG}$ islands. Alegría-Torres et al. demonstrated that DNA methylation may provide a novel indicator of the early environmental impact of PAHs exposure on gene function. They found associations between IL-12 and p53 DNA methylation and PAHs exposure, even at low concentration. In our study we analyzed the methylation in p53 gene as a potential biomarker. Based on our results it seems that the methylation of p53 is affected neither by psoriasis nor by GT, and therefore, the methylation in investigated $\mathrm{CpG}$ sites of $\mathrm{p} 53$ would not be a suitable bioindicator for genotoxic risk of GT (29).

Blood DNA methylation is affected by exposure to environmental and lifestyle cancer risk factors such as smoking, alcohol, and other carcinogens (48). Exposure to solar UV radiation may also reduce DNA methylation in circulating lymphocytes (49). Therefore, blood methylation may provide a useful biomarker for monitoring the cancer risk. Genome-wide DNA hypomethylation is a decrease in the overall genomic methylcytosine content (compared to total cytosines) from approximately $4 \%$ in normal tissue to $2-3 \%$ in cancer tissue. Hypomethylation is present highly in repetitive and moderately repetitive sequences as well as in single-copy DNA sequences across the genome (50). In our study, we found 3.55/2.10-8.50 percent of 5-mC (median/lower-upper quartile) vs. 3.35/2.50-7.50 percent of 5-mC (median/lower-upper quartile) before and after GT. In the subgroup of smokers, we found 3.20/2.10-4.13 percent of 5-mC vs. 2.80/1.95-3.43 before and after GT. The difference between the percentage of 5-mC before and after GT was statistically not significant. However, the smokers' subgroup yields a visible reduction in 5-mC below $3 \%$ after treatment, which could indicate a higher genotoxic risk of GT.

\section{Conclusion}

The genotoxicity of PAHs and UV radiation (as a part of GT) relates to mutagenicity, carcinogenicity and epigenetic regulation.
Although this study shows an excellent efficacy for $3 \%$ CCT, the results for $\mathrm{p} 53$ in serum and the level of BPDE-DNA adducts after GT are concerning. The significantly elevated serum level of $\mathrm{p} 53$ protein and increased presence of BPDE-DNA adducts in peripheral lymphocytes after treatment support the assumption that GT presents an increased genotoxic risk. However, it must be acknowledged that BPDE-DNA adducts also reflect individual variations in metabolic enzyme activity (different extent of bioactivation of BaP to BPDE) as well as the overall efficiency of DNA/RNA repair system. In the smokers' subgroup, we found a reduction in 5-mC below $3 \% \mathrm{CCT}$ after treatment, which could indicate an increased genotoxic risk of GT in these patients. Our study also shows that the analysis of methylation in selected $\mathrm{CpG}$ sites of $\mathrm{p} 53$ gene is not a suitable marker for monitoring the genotoxic effect related to GT.

\section{References}

1. Lebwohl MG, Bachelez H, Barker J, Girolomoni G, Kavanaugh A, Langley RG et al. Patient perspectives in the management of psoriasis: results from the population-based Multinational Assessment of Psoriasis and Psoriatic Arthritis Survey. J Am Acad Dermatol 2014; 70 (5): 871-881 e1-30.

2. Sewerin P, Brinks R, Schneider M, Haase I, Vordenbaumen S. Prevalence and incidence of psoriasis and psoriatic arthritis. Ann Rheum Dis 2019; 78 (2): 286-287.

3. Akcilar R, Namdar ND, Kocak FE, Bayat Z, Burhan H. ADAM 33 gene V4 C/G rs2787094 polymorphism in psoriasis. Bratisl Lek Listy 2018; 119 (7): 454-457.

4. Lara-Corrales I, Ramnarine S, Lansang P. Treatment of childhood psoriasis with phototherapy and photochemotherapy. Clin Med Insights Pediatr 2013; 7: 25-33.

5. Seyhan M, Coskun BK, Saglam H, Ozcan H, Karincaoglu Y. Psoriasis in childhood and adolescence: evaluation of demographic and clinical features. Pediatr Int 2006; 48 (6): 525-530.

6. Ranna D, Andrys C, Krejsek J, Hamakova K, Kremlacek J, Fiala Z et al. Elevated levels of circulating biomarkers of cell death (nucleosomes) in the patients with plaque psoriasis treated with the Goeckerman regimen. Bratisl Lek Listy 2014; 115 (4): 229-232.

7. Orseth ML, Cropley TG. What's in a name?: Goeckerman therapy. JAMA Dermatol 2013; 149 (12): 1409.

8. Paghdal KV, Schwartz RA. Topical tar: back to the future. J Am Acad Dermatol 2009; 61 (2): 294-302.

9. Borska L, Andrys C, Krejsek J, Palicka V, Chmelarova M, Hamakova $\mathrm{K}$ et al. Oxidative damage to nucleic acids and benzo (a)pyrene-7,8diol-9,10-epoxide-DNA adducts and chromosomal aberration in children with psoriasis repeatedly exposed to crude coal tar ointment and UV radiation. Oxid Med Cell Longev 2014; 2014: 302528.

10. Borska L, Andrys C, Krejsek J, Hamakova K, Kremlacek J, Palicka $\mathbf{V}$ et al. Genotoxic and apoptotic effects of Goeckerman therapy for psoriasis. Int J Dermatol 2010; 49 (3): 289-294.

11. Moorthy B, Chu C, Carlin DJ. Polycyclic aromatic hydrocarbons: from metabolism to lung cancer. Toxicol Sci 2015; 145 (1): 5-15.

12. Guo L, Jiang X, Tian HY, Yao SJ, Li BY, Zhang RJ et al. Detection of BPDE-DNA adducts in human umbilical cord blood by LC-MS/MS analysis. J Food Drug Anal 2019; 27 (2): 518-525. 
13. Sage E, Girard PM, Francesconi S. Unravelling UVA-induced mutagenesis. Photochem Photobiol Sci 2012; 11 (1): 74-80.

14. IARC Monographs on the evaluation of Carcinogenic Risks to Human. Agents Classified by the IARC Monographs. International Agency for Research on Cancer. Lyon: Cedex 08 2014: 1-109.

15. Burke KE, Wei H. Synergistic damage by UVA radiation and pollutants. Toxicol Ind Health 2009; 25 (4-5): 219-224.

16. Douki T, Ksoury Z, Marie C, Favier A, Ravanat JL, Maitre A. Genotoxicity of combined exposure to polycyclic aromatic hydrocarbons and UVA--a mechanistic study. Photochem Photobiol 2008; 84 (5): 1133-1140.

17. Lane DP, Lu X, Hupp T, Hall PA. The role of the p53 protein in the apoptotic response. Philos Trans R Soc Lond B Biol Sci. 1994; 345 (1313): 277-280.

18. Tuck SP, Crawford L. Characterization of the human p53 gene promoter. Mol Cell Biol. 1989; 9 (5): 2163-2172.

19. Spike BT, Wahl GM. p53, Stem Cells, and Reprogramming: Tumor Suppression beyond Guarding the Genome. Genes Cancer 2011; 2 (4): 404-419.

20. Han ES, Muller FL, Perez VI, Qi W, Liang H, Xi L et al. The in vivo gene expression signature of oxidative stress. Physiol Genomics 2008; 34 (1): $112-126$

21. Rossner P, Jr., Binkova B, Milcova A, Solansky I, Zidzik J, Lyubomirova KD et al. Air pollution by carcinogenic PAHs and plasma levels of p53 and p21 (WAF1) proteins. Mutat Res 2007; 620 (1-2): 34-40.

22. Bakry R, El-Sayed MI, Hamza HM, Hassan KH. Pretreatment levels of serum osteoprotegerin and $\mathrm{p} 53$ protein and urine telomerase as prognostic factors affecting survival in Egyptian bladder cancer patients. Oncol Lett 2016; 11 (1): 823-830.

23. Gayon J. From Mendel to epigenetics: History of genetics. C R Biol 2016; 339 (7-8): 225-30.

24. Kanwal R, Gupta K, Gupta S. Cancer epigenetics: an introduction. Methods Mol Biol 2015; 1238: 3-25.

25. Das PM, Singal R. DNA methylation and cancer. J Clin Oncol 2004; 22 (22): 4632-4642.

26. Masciarelli S, Bellissimo T, Iosue I, Fazi F. The Methylated DNA Immunoprecipitation [MeDIP] to Investigate the Epigenetic Remodeling in Cell Fate Determination and Cancer Development. Methods Mol Biol 2016; 1379: 69-76.

27. Yang X, Han H, De Carvalho DD, Lay FD, Jones PA, Liang G. Gene body methylation can alter gene expression and is a therapeutic target in cancer. Cancer Cell 2014; 26 (4): 577-590.

28. Christensen BC, Marsit CJ. Epigenomics in environmental health. Front Genet 2011; 2: 84 .

29. Alegria-Torres JA, Barretta F, Batres-Esquivel LE, CarrizalesYanez L, Perez-Maldonado IN, Baccarelli A et al. Epigenetic markers of exposure to polycyclic aromatic hydrocarbons in Mexican brickmakers: a pilot study. Chemosphere 2013; 91 (4): 475-480.

30. Hernandez-Boussard T, Rodriguez-Tome P, Montesano R, Hainaut P. IARC p53 mutation database: a relational database to compile and analyze p53 mutations in human tumors and cell lines. International Agency for Research on Cancer. Hum Mutat. 1999; 14 (1): 1-8.

31. Borska L, Andrys C, Krejsek J, Hamakova K, Kremlacek J, Ranna D et al. Plasma levels of p53 protein and chromosomal aberrations in patients with psoriasis treated with the Goeckerman regimen. Clin Exp Dermatol 2009; 34 (8): e881-883.
32. de Rie MA, Goedkoop AY, Bos JD. Overview of psoriasis. Dermatol Ther 2004; 17 (5): 341-349.

33. Herman JG, Graff JR, Myohanen S, Nelkin BD, Baylin SB. Methylation-specific PCR: a novel PCR assay for methylation status of $\mathrm{CpG}$ islands. Proc Natl Acad Sci U S A. 1996; 93 (18): 9821-9826.

34. Amatya VJ, Naumann U, Weller M, Ohgaki H. TP53 promoter methylation in human gliomas. Acta Neuropathol 2005; 110 (2): 178-184.

35. Yan YX, Jiang JW, Huang ZH, Wu ZH, Lin CL, Wu FY. Antisense oligonucleotides targeting protein kinase $\mathrm{C}$ alpha inhibits the proliferation of A549 cells. Nan Fang Yi Ke Da Xue Xue Bao 2009; 29 (6): 1189-1191.

36. Kim J, Yu L, Chen W, Xu Y, Wu M, Todorova D et al. Wild-Type p53 Promotes Cancer Metabolic Switch by Inducing PUMA-Dependent Suppression of Oxidative Phosphorylation. Cancer Cell 2019; 35 (2): 191$203 \mathrm{e} 8$.

37. Oren M, Rotter V. Introduction: p53 - the first twenty years. Cell Mol Life Sci. 1999; 55 (1): 9-11.

38. Lane DP. Cancer. p53, guardian of the genome. Nature 1992; 358 (6381): 15-16.

39. Hainaut P, Hernandez T, Robinson A, Rodriguez-Tome P, Flores T, Hollstein M et al. IARC Database of p53 gene mutations in human tumors and cell lines: updated compilation, revised formats and new visualisation tools. Nucleic Acids Res 1998; 26 (1): 205-213.

40. Husgafvel-Pursiainen K, Kannio A, Oksa P, Suitiala T, Koskinen H, Partanen R et al. Mutations, tissue accumulations, and serum levels of p53 in patients with occupational cancers from asbestos and silica exposure. Environ Mol Mutagen 1997; 30 (2): 224-230.

41. Gao D, Luo Y, Guevara D, Wang Y, Rui M, Goldwyn B et al. Benzo[a] pyrene and its metabolites combined with ultraviolet A synergistically induce 8-hydroxy-2'-deoxyguanosine via reactive oxygen species. Free Radic Biol Med 2005; 39 (9): 1177-1183.

42. Pauk N, Klimesova S, Kara J, Topinka J, Labaj J. The relevance of monitoring of antibodies against the polycyclic aromatic hydrocarbon (PAH) and PAH-DNA adducts in serum in relation to lung cancer and chronic obstructive pulmonary disease (COPD). Neoplasma 2013; 60 (2): 182-187.

43. Chuang JC, Jones PA. Epigenetics and microRNAs. Pediatr Res 2007; 61 (5 Pt 2): 24R-29R

44. Mahmood N, Rabbani SA. Targeting DNA Hypomethylation in Malignancy by Epigenetic Therapies. Adv Exp Med Biol 2019; 1164: 179-196. 45. Singal R, Ginder GD. DNA methylation. Blood. 1999; 93 (12): 4059 4070.

46. Prokhortchouk E, Hendrich B. Methyl-CpG binding proteins and cancer: are MeCpGs more important than MBDs? Oncogene 2002; 21 (35): 5394-5399.

47. Cedar H, Bergman Y. Linking DNA methylation and histone modification: patterns and paradigms. Nat Rev Genet 2009; 10 (5): 295-304.

48. Brennan K, Flanagan JM. Is there a link between genome-wide hypomethylation in blood and cancer risk? Cancer Prev Res (Phila) 2012; 5 (12): 1345-1357.

49. Nair-Shalliker V, Dhillon V, Clements M, Armstrong BK, Fenech M. The association between personal sun exposure, serum vitamin $\mathrm{D}$ and global methylation in human lymphocytes in a population of healthy adults in South Australia. Mutat Res 2014; 765: 6-10.

50. Ehrlich M. DNA methylation in cancer: too much, but also too little. Oncogene 2002; 21 (35): 5400-5413.

Received March 6, 2020. Accepted April 6, 2020. 